\title{
INTERNATIONAL COURTS AND LEGALISM IN INTERNATIONAL LAW
}

\section{Adam Wiśniewski*}

\begin{abstract}
In this article, I argue that legalism, understood as a stronger commitment of states (and other subjects) to the observance of the rules of international law, was fostered by the dynamic development of international courts and tribunals, which started in the 1990s. This contribution has manifested itself in various ways, both external and internal. The multiplication of international courts, coupled with the widespread compulsory jurisdiction, has been crucial to strengthening state commitment to adhere to their international obligations. The interpretation and application of international norms ceased to depend solely on the subjective discretion of states. Therefore, judicialisation is rightly presented as a process of taming the Leviathan and gradually subjecting it to the international rule of law. The problem of legalism in the context of international courts can, and should, also be examined in its "internal" aspect. This entails the examination of a number of issues connected with the courts' status, competence, function, case law coherence and stability, judgment implementation, etc. Despite the problems and risks involved, the proliferation of international courts and tribunals can be perceived as one of the most important components of the dynamic transition of international law in recent decades.
\end{abstract}

* Professor at University of Gdańsk, Faculty of Law and Administration, Department of Public International Law 
In this sense, one might argue that Hart was right in claiming that the functioning of courts, endowed with compulsory jurisdiction, is one of the conditions for recognising international law as genuine law.

Another important effect of the judicialisation on international law is that, at the very least, certain international norms have acquired "objective" nature, detached from the will of states. This is due to the interpretation and application of these norms no longer depending solely upon the subjective discretion of states, but rather becoming subject to consideration and examination by an independent judicial body.

Judicialisation is, thus, rightly presented as a process of taming the Leviathan and gradually subjecting it to the international rule of law. Beyond any doubt, this process and its consequences markedly change the face of international law. The multiplication of international courts results in expanding the judicial institutional layer, making international law less horizontal. Additionally, in consequence of growing case law, the system of international law becomes more complex, developed, and mature. The development of international law is a natural aspect of the judicial function. This is due to the fact that international norms are, in many cases, incomplete and unclear, necessitating their interpretation, adaptation, and development in particular cases.

\section{Introduction}

Although the term legalism is sometimes understood differently by legal scholars, few would disagree that its core meaning refers to compliance with legal rules. Legalism is thus understood as an important formal component of the rule of law, especially as regards the requirement that the organs of state should abide by legal regulations. Insofar as the international rule of law is understood as the idea that actors in the international system should abide by existing international law, ${ }^{1}$ it appears to be nearly synonymous with the notion of legalism.

One should not overlook, however, certain negative connotations of the term legalism, especially when it is understood as an attitude towards

1 B.P. Chimni, Legitimating the international rule of law, [in:] J. Crawford, M. Koskenniemi, P. Ranganathan, 'The Cambridge Companion to International Law', Cambridge University Press, Cambridge 2012 at p. 292. 
law, which is characterised by an excessive conformity to law or legal rules. In this sense, it is possible to talk about legalism in international law in the context of massive violations of human rights, when strict adherence to international legal rules, as opposed to human rights, may seem unacceptable on moral grounds. Thus, the 1999 NATO bombing of Yugoslavia was defended as legitimate; although, it had no legal basis. ${ }^{2}$

There are, however, also those who note the positive or moral value of legalism. For example, this is the position taken by the political philosopher Judith N. Shklar in her influential book Legalism: Law, Morals, and Political Trial, published by Harvard University Press in 1964. She defines legalism as "the ethical attitude that holds moral conduct to be a matter of rule following, and moral relationships to consist of duties and rights determined by rules." ${ }^{3}$ However, as it was observed by one author, legalism that consists of a commitment to the morality of playing by the rules seems oddly inappropriate in the international arena. ${ }^{4}$

At times, the proposed meaning of legalism appears to be exceedingly broad. For example, according to Eric E. Posner, "legalism is a complicated and ambiguous concept, and any attempt to reduce it to a definition is hazardous." In his view, while components of legalism include rules and procedures, the powerful role of judges is its crucial element. ${ }^{5}$ The broad notion of legalism, as proposed by Posner, does not seem appropriate because, first of all, it becomes all-inclusive, thus losing its edge. On the other hand, if legalism is simply to mean conformity or adherence to law, then one can rightly ask why use the term legalism if the same can be expressed by well-known terms, such as "legality" or "conformity"? It is, therefore, proposed that, for the purposes of this study, legalism is to be understood as a stronger commitment of states (and other subjects) to the observance of the rules of international law.

The present study aims to examine the significance of international courts for legalism in international law and international relations. The expansion of international courts and tribunals, which began in the 1990s, had a profound effect on the field of international law. Taking into account

2 J. Zajadło, Dylematy humanitarnej interwencji [Dilemmas of Humanitarian Intervention], Arche, Gdańsk 2005, at p. 7.

3 Judith N. Shklar, Legalism: Law, Morals, and Political Trial, Harvard University Press, 1964, at p. 1.

4 R. West, Reconsidering Legalism, 'Minnesota Law Review' 2003, vol. 88, at p. 126.

5 E.A. Posner, The Perils of Global Legalism, The University of Chicago Press, Chicago, at p. 8 . 
the relative weakness of other branches of international law system, i.e. the executive and legislative branch, the dynamic strengthening of the international judicial branch offers some basis for hope that international law will progress from being power-based to a more rule-based international order. ${ }^{6}{ }^{7}$

It is assumed here that the dynamic development of international courts and tribunals has contributed to the increased presence of legalism in international law and international relations in various ways. In fact, some authors understand judicialisation as a particular form of legalisation, characterised by a high degree of delegation to adjudicative institutions. ${ }^{8}$ In this sense, the increase of judicialisation in international relations can be regarded as conducive to higher degree of legalism in international law; although, obviously, there are numerous other factors to be considered. It would be impossible to consider here all possible implications of the international judicialisation for legalism in the system of international law, especially in the context particular international courts. Therefore, this paper is rather a modest attempt at outlining certain preliminary observations or theoretical proposals, at a general theoretical level, regarding the consequences of the dynamic expansion of international courts and tribunals for legalism in international law. From the methodological point of view, these theoretical proposals should rather be treated as a hypothesis, subject to further verification based, in particular, on analytical and empirical research focused on the activities of respective courts and tribunals. Another reservation, which has to be made at the outset, is that this study is not based on a detailed analysis of legal instruments constituting the basis for the operation of respective international courts and tribunals,

6 Y. Shany, Assessing the Effectiveness of International Courts, Oxford University Press, Oxford 2014, at p. 1.

7 An international court is understood in this article as a body of a permanent and independent nature, created by an international instrument, functioning in accordance with the established procedure and on the basis of international agreements, whose decision is binding upon the parties to a dispute. W. Czapliński, Multiplikacja sq̨ów międzynarodowych - szansa czy zagrożenie dla jedności prawa międzynarodowego [Multiplication of International Courts - Opportunity or Threat for the Unity of International Law?], [in:] J. Kolasa, A. Kozłowski, 'Rozwój prawa międzynarodowego - jedność czy fragmentacja' [The Development of International Law - Unity or Fragmentation], Wrocław 2007, at p. 78.

8 C.P.R. Romano, The Shift from the Consensual to the Compulsory Paradigm in International Adjudication: Elements for a Theory of Consent, 'International Law and Politics' 2007, vol. 39, at p. 797. 
nor is it concerned with their, at times increasingly voluminous, case law. This would exceed the limits of this paper, which aims to conduct a theoretical and conceptual analysis of the phenomenon of multiplication of international courts and tribunals, together with its possible impact on the system of international law as perceived from the holistic perspective. This approach is based, at least in part, on the assumption that, at present, there is a need for a more theoretical and general analysis of various aspects of international law, whereas the focus of international law studies has, thus far, been on specific issues, lacking a more general background and perspective.

The main points of interest for this study include a debate on the compulsory jurisdiction of international courts, as well as their proliferation in the 1990s and its ramifications for legalism and its limitations. The starting point, however, is Hart and his doubts regarding the legal nature of international law.

\section{Hart, international courts, and compulsory jurisdiction}

According to Hart, in the absence of institutions such as an international legislature, courts with compulsory jurisdiction, and centrally organised sanctions, the international law resembles "that simple form of social structure, consisting only of primary rules of obligation, which, when we find it among societies of individuals, we are accustomed to contrast with developed legal system." To Hart, an important source of doubt regarding the legal character of international law was the absence of secondary rules of change and adjudications providing for legislature and courts, as well as "a unifying rule of recognition specifying 'sources' of law and providing general criteria for the identification of its rules." ${ }^{\prime 10}$ Thus, it is clear that the existence of courts in international law was to him one of the conditions for recognising that "international law is really law." ${ }^{11}$ It is also important to note that, for Hart, it were not just any courts that mattered but courts with compulsory jurisdiction, specifically.

9 H.L.A. Hart, The Concept of Law, Oxford University Press, Oxford 1984, at p. 209.

10 Ibid.

11 Ibid. 
It is, thus, not surprising that representatives of international law doctrine had spent nearly a century, since 1880 , advocating for the establishment of international courts with compulsory jurisdiction. The notion of compulsory jurisdiction of international courts is in contradiction to the idea of state sovereignty and, therefore, strictly speaking inaccurate, especially when applied to litigation between states. ${ }^{12}$ It is universally recognised that a sovereign State can never be sued before any court by another State unless it has accepted the jurisdiction of the court in question. This was confirmed by the Permanent Court of International Justice in the Eastern Carelia case, when the Court said that it is well established in international law that no state can, without its consent, be compelled to submit its disputes with other states either to mediation or to arbitration or to any other kind of pacific settlement. ${ }^{13}$ Therefore, the phrase "compulsory jurisdiction" is used in international law in a different sense than in internal law, i.e. rather loosely, meaning the jurisdiction conferred by a general agreement between States to submit disputes, usually of a defined character, to a particular tribunal. ${ }^{14}$

As it was noted by some authors, the growing trend in favour of international jurisdiction can be traced back to the first serious discussions about an international court, in the 1870 s. ${ }^{15}$ When it came to the drafting of the statute of the Permanent Court of International Justice in 1920, Lord Philimore suggested that it ought to be a "Court of Justice in the true sense of the word, a court before which it should be possible to call States having broken the law of Nations, without having to obtain their consent in advance. ${ }^{.16}$ Despite the fact that this idea found some supporters among the lawyers of the Advisory Committee of Jurists, with one of them suggesting that compulsory jurisdiction would be a major step forward and away from arbitral jurisdiction, other members were against it, some, characteristically, claiming that the time was not yet ripe for compulsory jurisdiction. ${ }^{17}$

12 A.P. Fachiri, The Permanent Court of International Justice, London 1932, at p. 5, cited after R.P. Anand, Compulsory Jurisdiction of the International Court of Justice, Delhi 2008, at p. 28.

13 Eastern Carelia Case, 'Hudson's World Court Reports', vol. I, at p. 204.

14 A.P. Fachiri, op.cit., at p. 5.

15 M.E. O'Connel, L. Venderzee, The History of International Adjudication, [in:] C.P.R. Romano, K.J. Alter, Y. Shany, 'The Oxford Handbook of International Adjudication', Oxford University Press, Oxford 2014, at p. 53.

16 Ibid.

17 Ibid. 
Eventually, a compromise was reached to the effect that states could elect to be bound by the compulsory jurisdiction of the court either through compromissory clauses in treaties or by accepting the "optional clause." In Article 36 of the Statute of the PCIJ, it was provided that:

the Members of the League of Nations and the States mentioned in the Annex to the Covenant may, either when signing or ratifying the Protocol to which the present Statute is adjoined, or at a later moment, declare that they recognize as compulsory ipso facto and without special agreement, in relation to any other Member or State accepting the same obligation, the jurisdiction of the Court in all or any of the classes of legal disputes.

This declaration could be made unconditionally or on the condition of reciprocity on the part of several, or selected, Members or States, or for a limited time. This optional compulsory jurisdiction was accepted by 21 states, including many of the world's great powers at the time. ${ }^{18}$ This system of optional acceptance of the PCIJ jurisdiction was the most that it could hope to achieve in 1920. By way of comparison, to this day, 72 states have accepted the compulsory jurisdiction of the International Court of Justice pursuant to Article 36 section 2 of the Statute.

Thus, in principle, the PCIJ was open to all States for the judicial settlement of their international disputes. States could declare beforehand that, for certain classes of legal disputes, they recognised the Court's jurisdiction as compulsory in relation to other States accepting the same obligation.

After the Second World War, the most ardent advocate of the unlimited compulsory jurisdiction of the International Court, in all disputes arising between states, was Hans Kelsen. He argued that the jurisdiction based on Article 36 section 2 of the ICJ Statute is not compulsory in the true sense of the word. ${ }^{19}$ The author of Principles of International Law asserted that in view of a true compulsory jurisdiction of the International Court of Justice:

the Statute would have to provide that any member of the judicial community, party to any case whatever, is obliged to recognize the jurisdiction of the Court if the other party refers the dispute to the Court. But it provides only for the possibility of entering into

18 Ibid.

19 H. Kelsen, The Law of the United Nations, London 1950, at p. 522. 
agreements for the establishment of the jurisdiction of the Court, in advance and in a general way. ${ }^{20}$

Kelsen further argued that the difference between the so-called compulsory jurisdiction, as established by Article 36 section 2 of the Statute, and the provisions of a genuine compulsory jurisdiction proposed by himself, is only relative, since both depend upon consent. At the same time, he claimed that it made a "remarkable difference whether the Statute of the tribunal obliges directly any party to any possible dispute to accept the jurisdiction of the tribunal or whether the Statute... only offers the possibility [of entering into the aforementioned agreements for the establishment of the jurisdiction of the Court]." ${ }^{21}$ Kelsen was aware of the states' resistance when it came to the acceptance of compulsory jurisdiction; nevertheless, he thought it necessary to establish a judicial system capable of guaranteeing, insofar as it is possible, that all disputes between states are subject to compulsory jurisdiction. ${ }^{22}$

It was, certainly, utopian to think that all disputes between states could be decided by a court. However, the underlying assumption behind the Kelsen advocacy for compulsory jurisdiction was based on a belief that this would be the most important step towards transforming the present primitive international law into a more advanced legal order. ${ }^{23}$ According to Kelsen, this would be the greatest advance in the history of the determination of the question of right and wrong, whereby courts, rather than states, would be entrusted with delivering an impartial and objective decision in this respect. ${ }^{24}$ This closely resembles what Hart wrote, when he discussed the issue of international law as a real law.

The debate and struggle for the compulsory jurisdiction of world courts eventually faded. ${ }^{25}$ Instead, in the 1990s, an important phenomenon emerged - the dynamic development of international courts and tribunals, most of which were invested with some degree of compulsory jurisdiction.

Ibid.

Ibid, at pp. 522-523.

23 R.P. Anand, op. cit., at p. 80.

24 Ibid, at p. 80.

25 M.E. O'Connel, L. Venderzee, op. cit., at p. 60. 


\section{Multiplication of international courts}

The dynamic multiplication of international courts and tribunals, which took place in the 1990s, was described by some authors as one of the "most significant changes in international law (and, correspondingly, international relations) of our time." ${ }^{26}$ By the end of the 1980s, there were six permanent international courts. In addition, the non-compulsory dispute settlement system of the General Agreement on Tariffs and Trade (GATT) should be mentioned. Over the next two decades, the number of international courts and tribunals increased to more than 20 operational permanent international courts, including four with a global reach. These included the ICJ, the International Tribunal for the Law of the Sea (ITLOS), the Appellate Body of the World Trade Organization (WTO AB), and the International Criminal Court. Other courts and tribunals have regional jurisdiction and are located in Africa (9), Europe (6), and Latin America (5). ${ }^{27}$

One of the features of international courts and tribunals is their diverse nature. It is suggested that international judicial bodies can be divided into five distinct types, based on their fundamental jurisdictional and institutional attributes. ${ }^{28}$ As already mentioned, international courts are heterogeneous in character. Although, at the outset, their main purpose was to peacefully settle international disputes, nowadays, only three courts have such competence. The most important of them is the International Court of Justice, acting as a world court with the jurisdiction to decide all disputes of legal nature that are submitted to it by states. The other two courts, namely ITLOS and the WTO AB, have more specialised jurisdiction. ${ }^{29}$ The International Tribunal for the Law of the Sea has jurisdiction over all disputes concerning the interpretation or application of the United Nations Convention on the Law of the Sea, as well as all over other agreements conferring jurisdiction on the Tribunal, whereas the WTO AB

26 Cf. C.P.R. Romano, The Shift..., op. cit., at p. 794.

27 Cf. K.J. Alter, The Multiplication of International Courts and Tribunals After the End of the Cold War, [in:] C.P.R. Romano, K.J. Alter, Y. Shany, 'The Oxford Handbook...', p. 65.

28 C.P.R. Romano, K.J. Alter, Y. Shany, Mapping International Adjudicative Bodies, The Issues, and Players, [in:] C.P.R. Romano, K.J. Alter, Y. Shany, 'The Oxford Handbook of International Adjudication', Oxford University Press, 2014, p. 12.

29 C.P.R. Romano, K.J. Alter, Y. Shany, Mapping..., op.cit. , at p. 12. 
hears appeals from reports issued by panels in disputes brought by WTO members. Some authors call these courts the "old type courts." 30

The second type of international courts are the human rights courts which are competent to hear cases concerning violations of human rights protected under international law. At present, there are three such courts, namely the European Court of Human Rights (ECHR), the Inter-American Court of Human Rights (IACHR), and the African Court on Human Rights (ACHR), the creation of which followed the example of the ECHR. Most of the cases decided by these courts concern individual complaints. Although they are competent to hear also interstate complaints, such cases are rare.

The third type are the courts set up as part of regional organisations dealing with economic cooperation and integration. This is the largest group: according to some authors, there are approximately 20 such courts in the world, based on formally negotiated legal instruments establishing regional courts. Some of these courts follow the model of the Court of Justice of the European Union, as the most recognisable and effective international court. Other regional arrangements for regional economic co-operation, follow the example of the WTO dispute settlement system, and yet others choose a mixed model. ${ }^{31}$ The most striking feature of the courts within this group is the complexity of the subject matter of their jurisdiction. These courts can hear cases brought before them directly by the parties affected by community rules; deal with actions alleging non-compliance, initiated by one Member State against another, and hear complaints brought by community institutions, alleging that rules were adopted in violation of procedural requirements or provisions of regional agreements. Some also act as international administrative tribunals. Moreover, these courts are usually competent to consider questions of the interpretation of community rules submitted by national courts. ${ }^{32}$

The fourth group includes international criminal courts and tribunals, which are characterised by their criminal jurisdiction over individuals charged with committing international crimes, usually high-ranking politicians, military leaders, and commanders. These are the only international bodies deciding on the accountability of individual people.

30 C.P.R. Romano, K.J. Alter, Y. Shany, Mapping..., op.cit., at p. 12.

31 For example, the North American Free Trade Agreement dispute settlement relies on ad hoc arbitral panels, whereas the Andean Tribunal of Justice is cited as an example of a mixed model. C.P.R. Romano, K.J. Alter, Y. Shany, op. cit., at p. 13-14.

32 C.P.R. Romano, K.J. Alter, Y. Shany, Mapping..., op.cit., at p. 13. 
The first permanent, treaty-based, international criminal court was the International Criminal Court (ICC), established under the Rome Statute. There are also ad hoc international tribunals, since the Nuremberg and Tokyo trials. In the 1990s, international criminal tribunals ad hoc were established in response to atrocities committed during the conflict in the former Yugoslavia and the mass-killings in Rwanda. The International Criminal Tribunal for the former Yugoslavia (ICTY) and its sister court for Rwanda (ICTR) were both created by the UN Security Council on the basis of the UN Charter provisions. Following the creation of these two ad hoc tribunals, special, mixed, or hybrid tribunals have been established to prosecute domestic and international crimes, examples of which can be found in Kosovo, Sierra Leone, East Timor, Bosnia Herzegovina, Cambodia, and Lebanon. ${ }^{33}$

The fifth group are international administrative tribunals. These are judicial bodies attached to an international organisation, which are competent to decide in disputes between the organisation and its staff members. Although such courts qualify as international courts, they often bear some resemblance to domestic labour courts. ${ }^{34}$

An important feature of the aforementioned proliferation of courts and tribunals is their supranational character, which means that increasingly more often the parties to litigation are non-state actors, including natural persons. Moreover, judicial disputes initiated by individuals against their own states are on the rise. This has an important effect of growing case law which is not a product of inter-state disputes but of proceedings initiated by non-state actors. Another distinct feature of the dynamic development of international courts in the 1990s is that it was not systematic but rather largely uncoordinated, and, to a great extent, a process of trial and error. ${ }^{35}$ This lack of coordination resulted in a number of potential problems consisting mainly in possible conflicts of jurisdictions and case law, as discussed below. The uncoordinated judicialisation turned out to be uneven both geographically and as regards the subject matter of the courts' jurisdiction. The degree of judicialisation appears to vary a great deal among various regions of the world. On the one hand, the most effective international or supranational courts, such as the Court of Justice of

33 Ibid, at p. 14.

34 Ibid.

35 C.P.R. Romano, Trial and Error in International Judicialization, [in:] C.P.R. Romano, K.J. Alter, Y. Shany, op. cit., at p. 132. 
European Union (CJEU) and the European Court of Human Rights (ECHR), were established and operate in Europe. On the other hand, Asia appears to remain unaffected by the trend towards judicialisation of international relations. This is a result of the specific feature of the international community - made up primarily of sovereign states, which, in regions such as Asia, resist the trend toward judicialisation - and is connected to an array of political, cultural, historical, and other factors. ${ }^{36}$

Notwithstanding the general jurisdiction of the ICJ and apart from human rights and the subject matter of the jurisdiction of international criminal courts, international courts deal mostly with economic matters, such as property rights, free trade, or intellectual property rights. A significant number of subject areas either have not been covered by judicialisation or only occasionally reach a tribunal. According to Benedict Kingsbury, examples include most military and intelligence issues, including arms control, disarmament, nuclear weapons, and nuclear energy governance; global financial governance; urban policy and climate, local government; corruption; land, forests, water, air, political decision processes; hazardous waste; humanitarian assistance and disaster response; most issues affecting people's lives in poor countries, etc. ${ }^{37}$ This is one of the reasons that the establishment of new international tribunals, competent to decide on at least some of the above issues, is advocated. For example, it has been suggested that an international court for the environment ought to be created.

The expanded international courts and tribunals do not form any hierarchical structure but operate horizontally. There is no relationship of subordination between them, so they are autonomous from each other. This results, to a large extent, from the fact that most of these international courts and tribunals have been created as parts of specialised regimes and not as courts with general jurisdiction, such as the ICJ..$^{38}$ This, in turn, is related to another important feature of international courts, which was described by some as revolutionary, namely compulsory jurisdiction. ${ }^{39}$ The compulsory jurisdiction does not mean that the consent of states to exercising international court jurisdiction has become unnecessary. Such consent

36 C.P.R. Romano, K.J. Alter, Y. Shany, Mapping..., op. cit., at p. 3-10.

37 B. Kingsbury, International Courts: Uneven Judicialisation in Global Order, [in:] J. Crawford, M. Koskenniemi, P. Ranganathan, 'The Cambridge Companion to International Law', Cambridge University Press, Cambridge 2012, at p. 212.

38 Ibid, at p. 211.

39 C.P.R. Romano, The Shift..., op. cit., at p. 795. 
is a requirement of state membership in an international organisation, or legal regime, and the adjudicative process typically starts with a unilateral submission. Consent is expressed at the very beginning, usually upon the ratification of treaties creating an international organisation endowed with adjudicative bodies. However, although the principle of consent remains, as C.P.R. Romano rightly observed, its significance has been gradually reduced. This is due to the fact that "the expression of consent has become so removed in time and substance from the exercise of jurisdiction that one may question whether consent continues to serve a significant function in the international order." ${ }^{40}$ This is the kind of compulsory jurisdiction that was advocated by Kelsen in relation to the ICJ. However, it should be noted, that states would not be so willing to accept compulsory jurisdiction of international courts and tribunals have they been invested with general jurisdiction rationae materiae, such as is the case with the ICJ. The willingness of states to accept compulsory jurisdiction was precisely a result of the limited subject-matter jurisdiction of the newly created courts.

This trend towards the proliferation of international courts and tribunals had a number of causes, one of them being the growing subject-matter of international law, with increasingly more issues being regulated by international law. Moreover, the development of integration organisations, such as the European Union, was a major factor. The growing volume and complexity of international norms implied the establishment of specialised adjudication bodies in order to secure the operation and effectiveness of the new legal arrangements. ${ }^{41}$ The success of the CJEU or ECHR was an important factor encouraging states in other geographical areas to set up similar judicial bodies. Some authors point to the easing of international tensions, which had previously been an obstacle to the development of adjudicative mechanisms, in the $1990 \mathrm{~s} .{ }^{42}$ A number of states resigned from their earlier reluctant approach to international adjudication, consenting to the compulsory jurisdiction of international courts and tribunals. ${ }^{43}$ Finally, the unsuitability of the ICJ and other pre-existing courts to deal with a growing number of disputes involving specialised legal adjudications also encouraged states to look for new international judicial fora.

${ }^{40}$ Ibid.

41 Y. Shany, Competing Jurisdictions of International Courts and Tribunals, Oxford University Press, Oxford 2003, at p. 3.

42 Ibid, at p. 4.

43 W. Czapliński, op.cit., at p. 83. 
It is interesting to note that the problem of legalism was considered when some of the courts were created. This refers to two ad hoc courts, namely the International Criminal Court for Former Yugoslavia and the International Criminal Court for Rwanda. In particular, it was alleged that the UN Security Council acted ultra vires when setting up these courts on the basis of the provisions of the UN Charter while the Charter did not provide a sufficient legal basis for the creation of an international criminal tribunal deciding on the criminal liability of individuals. ${ }^{44}$ On the other hand, the establishment of the International Criminal Court (ICC) was accompanied by a somewhat idealistic, and perhaps naïve, faith in the triumph of legalism in international law.

The multiplication of international courts and tribunals also brought about misgivings, especially as regards its implications for the system of international law. Due to the uncoordinated and decentralised process of international court creation, jurisdictions of various judicial bodies may potentially overlap, leading to the risk of jurisdictional conflicts. For example, due to the fact that the ICJ has jurisdiction to adjudicate any legal dispute between states, its jurisdiction may overlap not only with the jurisdiction of specialised international tribunals, such as ITLOS or the WTO, but also with the jurisdiction of regional courts, such as human rights tribunals. ${ }^{45}$ This, in turn, has led to the relatively new phenomenon in international relations, namely forum shopping. States are likely to have their legal case heard in the court thought most likely to provide a favourable judgment. According to some authors, this may have a positive outcome, for example, by introducing an element of competition among tribunals and improving the quality of rulings and the expediency of proceedings. ${ }^{46}$ If respective tribunals maintain a critical eye on one another, this may also increase the control over international tribunals and indirectly enhance their legitimacy. ${ }^{47}$ However, potential concerns are serious. The principle of the finality of rulings applies only to sequential proceedings, not to parallel proceedings conducted before autonomous and independent courts. Due

44 E. Socha, Karna odpowiedzialność jednostki w prawie międzynarodowym [Criminal Liability of an Individual in International Law], 'Kwartalnik Prawa Publicznego' 2002, vol. 2, no 4, at p. 94.

${ }^{45}$ Y. Shany, Competing Jurisdictions..., op. cit., at p. 8.

46 J. Pauwelyn, L.E. Salles, Forum Shopping before International Tribunals: (Real) Concerns, (Im)Possible Solutions, 'Cornell International Law Journal' 2009, vol. 42, no 1, at pp. 79-80.

47 Ibid. 
to the absence an international "supreme court" competent to correct inconsistent rulings, it is possible that in the event of contradictory judgments in the same case, the dispute will remain unresolved. Alternatively, new disputes could arise, fuelled by the situation. ${ }^{48}$

An even greater concern is that inconsistent rulings of various international courts would undermine the unity of international law, leading to its fragmentation. ${ }^{49}$ For example, such inconsistent rulings were given with respect to the standard of holding a state responsible for violations of international law. In the Military and Paramilitary Activities in and against Nicaragua case, the ICJ took the position that the requirement at issue is that of "effective control," whereas, in the Tadic case, the ICTY ruled in favour of the "overall control" standard..$^{50}$ Inconsistent rulings may negatively affect the effectiveness of international law and institutions, undermining their legitimacy.

Various proposals have been made as regards the ways of ensuring the consistency of international judicial bodies' judgements. For example, it has been suggested that the ICJ should become an appellate court for other international courts, following the example of internal legal systems, or that other international courts could submit questions to the ICJ. Another suggestion was that a new international court, with jurisdiction to rule on jurisdictional conflicts, should be established. Such institutional solutions would certainly enhance the rule of law and legalism in international relations; however, their implementation remains unlikely, as it would result in protracted court proceedings. What is more, states themselves would be unwilling to accept any of the aforementioned solutions, while the ICJ would not necessarily be the best court to rule in highly complex and specialised cases arising from specific international regimes.

On the other hand, non-institutional solutions emphasise the need for a dialogue among the judges, as well as their willingness to co-operate, be receptive, and engage with the case law of other courts. As Judge Guillame observed, such a dialogue is of crucial importance in order to address the dangers of fragmentation, and international judges "must inform themselves more fully of the case law developed by their colleagues, conduct more sustained relationships with other courts, in a word, engage in

48 Ibid, at p. 81.

49 R. Kwiecień, Teoria i filozofia prawa międzynarodowego. Problemy wybrane, [The Theory and Philosophy of International Law. Selected Issues] Difin, Warszawa 2011, at p. 101.

50 Ibid. 
constant inter-judicial dialogue." ${ }^{51}$ As Czapliński rightly observed, taking into account the dynamic multiplication of international courts, it is impossible to eliminate the divergences of rulings between various courts; nevertheless, such divergences exist also in the case of internal courts. Moreover, the risks of fragmentation are mitigated by the fact that various international courts make references to general international law, with its rules and principles. ${ }^{52}$ For example, all courts adopt the rules of interpretation provided in Articles 30 and 31 of the Vienna Convention of 1969. ${ }^{53}$

Another consequence of the dynamic yet uncoordinated proliferation of international courts and tribunals is that some of them either never start to operate or cease to function after only a few cases. Cesare Romano, mentions twenty such courts, including examples from the 1990s as well as the first decade of the 2000s, such as the Court of Justice of African Economic Community (1991), the Court of Conciliation and Arbitration of the Organization for Security and Cooperation in Europe (1994), the Court of the Union State between the Russian Federation and the Republic of Belarus (1999), the Court of Justice of the Central African Economic and Monetary Community (2000), and the Court of Justice of the African Union (2003). ${ }^{54}$ Romano is right in making an observation that international courts appear to be quite fragile institutions, more so than most international bodies. What they need is a careful design combined with a fair degree of peace and stability in the environments in which they are to operate. ${ }^{55}$ The success of the ECHR and the CJUE was, to a large extent, a result of the peaceful environment of Western Europe, providing these courts with a chance to develop their rich case law, whereas the aforementioned African courts had to cope with more politically polarised environments. ${ }^{56}$

51 StatementmadebyJudgeGuillaume, president of theICJ, to theUNGeneralAssembly, 26.10.2000 http:// www.icjcij.org/court/index.php?pr=84\&pt=3\&p1=1\&p2=3\&p3=1 (accessed on 28.4.2016).

${ }^{52}$ W. Czapliński, op. cit., at pp. 111, 130.

53 Ibid, at p. 111.

${ }_{54}$ C.P.R. Romano, Trial and Error..., op. cit., at pp. 113-114.

55 Ibid, at pp. 132-133.

56 Ibid, at p. 133. 


\section{Significance of international courts and tribunals for international legalism}

An assessment of the impact that creation and operation of international courts and tribunals had on legalism in international law would require a great deal of meticulous analysis, taking into account the specific nature of each international court. This is certainly a challenge for further in-depth research of the issue. For the purposes of this study, certain preliminary observations will be put forward. Despite the anticipated risks connected with the overlapping jurisdictions and case law of international courts and tribunals, the "proliferation" appears to have had a positive effect on the status of international law as law and, by the same token, on the issue of legality in international law. The expansion of international courts and tribunals resulted in the overall increasingly frequent resort to judicial fora and adjudication, thus enhancing the rule of law in international relations. ${ }^{57}$ It would, then, appear that the proliferation increased the impact of international law on the conduct of international relations. ${ }^{58}$

As Shany observed in his book Competing Jurisdictions of International Courts and Tribunals, the proliferation brought about an important qualitative change by encouraging states to treat their international obligations more seriously. ${ }^{59}$ This is because states are inclined to treat their international obligations more seriously when faced with the perspective of a judicial organ deciding about the alleged non-performance of such obligations. Perhaps even more important is the effect of the wide-spread compulsory jurisdiction where the role of consent is reduced to the act of ratification of the legal instrument constituting a given organisation, which soon becomes distant in time. The later withdrawal of such consent becomes increasingly difficult. Therefore, on a day-to-day basis, states face the initiation of judicial proceedings by other actors, very often non-state actors, without their consent in a given case. Obviously, as it was rightly observed by Kingsbury, "an international court will seldom induce a ... powerful state to do what its political elite and public are unified in refusing to do. ${ }^{\text {60 }}$ In fact, in some states, the problem of enforcing judgements

57 Y. Shany, Competing Jurisdictions..., op. cit., at p. 283.

58 P.M. Dupuy, J.E. Vinuales, The Challenge of "Proliferation": An Anatomy of the Debate,

[in:] C.P.R. Romano, K.J. Alter, Y. Shany (eds.), op. cit., at p. 140.

59 Y. Shany, Competing Jurisdictions..., op. cit., at p. 5.

60 B. Kingsbury, International courts..., op. cit., at p. 217. 
delivered by international courts remains. However, it is often the reciprocity and credibility of such states that is at stake. Accepting the jurisdiction of international courts makes one's international commitments more credible, whereas any subsequent non-performance of the courts' judgments undermines that credibility. ${ }^{61}$

Another important effect of the judicialisation on international law is that at least certain international norms acquired an "objective" nature, detached from the will of states. This is due to the interpretation and application of these norms no longer depending solely upon the subjective discretion of states, but rather becoming subject to consideration and examination by an independent judicial body. This objectivity is enhanced by the growing case law of international courts gradually developing interpretation of international norms, which have begun to be regarded as binding upon state-parties to a given treaty. A good example would be the voluminous case law of the ECHR, which with increasing precision defines the rights and freedoms protected under the European Convention of Human Rights, despite them being couched in very broad and general terms.

International courts also play an important role in developing the concept of jus cogens in international law, in that there are norms whose application is not dependent upon the state's will. ${ }^{62}$ While the significance of jus cogens norms for the system of international law and legalism cannot be overestimated, the concept itself remains unclear and contentious. ${ }^{63}$ It is important that jus cogens has been referred to in a number of judgments of both the Permanent Court of International Justice and the International Court of Justice, as well as in dissenting and separate opinions of various judges. In more recent case law, international courts have made attempts to examine various aspects of the concept in the international law system. For example, in decisions concerning the Jurisdictional Immunities of the State case and the Armed Activities in the Congo case, the ICJ addressed the relationship between jus cogens and procedural as well as secondary

61 Ibid.

62 See, inter alia, C. Mik, Ius cogens we wspótczesnym prawie międzynarodowym [Ius Cogens in Contemporary International Law] [in:] A. Wnukiewicz-Kozłowska, 'Aksjologia współczesnego prawa międzynarodowego' [Axiology of Contemporary International Law], Wydawnictwo Uniwersytetu Wrocławskiego, Wrocław 2011, at pp. 177-276.

63 D.D. Tladi, Jus cogens, Annex to the Report of the International Law Commission on the work of its sixty-sixth session (Agenda item 78), http://legal.un.org/ilc/reports/2014/ english/annex.pdf, at para. 3 . 
rules of international law. Thus, despite its significance, the concept of jus cogens norms remains, to a large extent, dependent upon its applicability by international courts and tribunals. ${ }^{64}$

Another important effect of the judicialisation is what some authors called "the judicial 'conquest' of the prerogative to determine the limits of what falls under the 'domaine réservé' of states at any given time." ${ }^{\prime 5}$ Again, this development limits the discretionary power of states to exclude certain matters from international review by courts. This is a particularly sensitive area when it comes to deciding, for example, human rights cases. Dupuy and Vinuales compare this to the assertion by domestic courts of the prerogative to review the constitutionality of executive and legislative action. $^{66}$

Judicialisation is thus rightly presented as a process of taming the Leviathan and gradually subjecting it to the international rule of law. ${ }^{67}$ Beyond any doubt, this process and its consequences markedly change the face of international law. The multiplication of international courts results in expanding the judicial institutional layer, making international law less horizontal. Additionally, in consequence of the growing case law, the system of international law becomes more complex, developed, and mature. The development of international law is a natural aspect of the judicial function. This is due to the fact that international norms are, in many cases, incomplete and unclear, necessitating their interpretation, adaptation, and development in particular cases. ${ }^{68}$

The case law of international courts, especially of the ICJ, plays also an important role in identifying and shaping the norms of customary law. As Cassese observed, "once the ICJ has stated that a legal standard is part of customary international law, few would seriously challenge such a legal finding." The Court thus plays an important role in international law-making. ${ }^{69}$

During the process of multiplication, it turned out that states are more willing to accept the compulsory jurisdiction of courts which had

64 P.M. Dupuy, J.E. Vinuales, The Challenge..., op. cit., at p. 139.

65 Ibid, at p. 141.

66 Ibid.

${ }^{67}$ Ibid, at pp. 138-139.

68 A. Wyrozumska, op. cit., at p. 5.

69 A. Cassese, The International Court of Justice: It is High Time to Restyle the Respected Old Lady, [in:] A. Cassese, 'Realizing Utopia. The Future of International Law', Oxford University Press, Oxford 2012, at p. 240. 
been set up within specialised legal regimes. As already mentioned, such acceptance - given only once, at the initial stage - becomes difficult to withdraw with the passage of time. In fact, the relationship between international courts and tribunals vis a vis sovereign states is characterised by constant friction. Their mutual interaction can be perceived as a dialectic process - dynamic, to a degree, and gradually changing the picture of international law and juridical nature. Various factors play an important role in this process, including international court diplomacy. Here, a good example can be found in the activity of the ECHR, set up in 1959. During the first decade following its establishment, the ECHR pronounced only ten judgements and found that the Convention was violated only in some cases. However, following so-called "human rights diplomacy" policy, the ECHR managed to win the trust of state-parties, allowing it to gradually introduce the living instrument doctrine in the 1970s, more than two decades after its creation. Based on this doctrine, the Strasbourg court was able to greatly develop the scope of human rights protection under the European Convention.

The problem of the friction in the relationship between courts and states ties up with the question of the legitimisation of particular courts and tribunals, as well as with their legitimacy being challenged, especially by states. In the case of some courts, especially human rights courts such as the ECHR, the argument of democratic deficit is often made, in particular, if such courts question acts taken at the national level by democratically elected bodies. Problems of legitimisation are often connected with the young age of a number of international courts, whose case law is often less developed than that of their national counterparts. A lack of trust can also result from the unequal treatment of various countries. For example, the ICC is often criticised for unfairly targeting African countries for prosecution, as the majority of its cases come from that continent.

What is the significance of the legitimisation of international courts and tribunals in the context of legalism? The courts which enjoy a degree of legitimacy may confer this legitimacy on norms and institutions constituting the regime in which they operate. ${ }^{70}$ This is connected with the level of legitimacy of international courts, which is dependent upon various factors, including their effectiveness. Undoubtedly, an effective court is more legitimised than one that is less effective. In fact, these two issues are interrelated, and thus international courts aim at being both legitimised 
and effective. The functioning of courts which are both effective and legitimised is conducive to a higher degree of legalism in treaty regimes within which they function, as exemplified by the CJUE and the ECHR.

This begs the question if the higher degree of legalism within particular treaty regimes affects the level of legalism in general international law? The answer to this questions appears to be, intuitively and prima facie, positive; however, it requires a great deal of research. The problem posed here brings to the attention another issue, namely that of the "internal" legalism of international courts and tribunals.

\section{International courts and "internal" legalism}

As mentioned in the introductory remarks, the problem of legalism in the context of international courts can, and should, also be examined in its "internal" aspect. This entails the examination of a number of issues connected with the courts' status, competence, functions, case law coherence, and stability, as well as judgment implementation, among others. Within the scope of this paper, it is only possible to make certain general observations; although, the problem of the internal legalism of international courts certainly merits a broader and more in-depth analysis.

First of all, it is certainly true that states may freely decide on the establishment of a court and the scope of its jurisdiction, etc. However, there are certain limits to this freedom. If a court is to have the status of a judicial body, it needs to have the powers necessary for independent decision making. ${ }^{71}$ Judges, in turn, have a duty to conduct fair hearings and decide impartially on the matters before them. As Dinah Shelton correctly observes, "[p]arties are more likely to submit their differences to judicial resolution if they expect and are afforded procedural fairness and a judgment based on the facts presented and the applicable law."72

Moreover, it is essential that international courts should follow their own procedures and statutes, as well as adhere to their own jurisdiction. This is because it affects their level of legitimacy, effectiveness, and judgment compliance. Naturally, there are more factors affecting the international courts' legitimacy of an institutional nature; these include, among

71 D. Shelton, Form, Function, and the Powers of International Courts, 'Chicago Journal of International Law' 2009, vol. 9, no 2.

72 Ibid. 
others, the way the court was set up, the selection of judges, their status of impartiality, etc. In order for a court judgement to play its role in the law-making process, there should be no procedural flaws: the decision should be made in line with the court's procedure, statute, and terms of the international agreement constituting the basis for its functioning. ${ }^{73}$ For the purpose of this study, it is important to emphasise that any positive impact of international courts on legalism in international law hinges on the condition of "internal" legalism being fulfilled.

The procedure of international courts has its roots, first of all, in relevant treaties, statutes, and regulations. For example, the Statute of the International Court of Justice is annexed to the Charter of the United Nations and forms an integral part of the Charter. The main object of the Statute is to organise the composition and the functioning of the Court. According to Article 1 thereof, the ICJ "shall function in accordance with the provisions of [the Statute]." Moreover, on the basis of Article 30 of the Statute, the Court outlined its Rules, which are meant to supplement the general rules set forth in the Statute. In the case of the ICC, its jurisdiction and functioning are governed by the Rome Statute, but this court also acts in accordance with the Rules of Procedure and Evidence, which are a subordinate instrument for the application of the Rome Statute. It is noteworthy that some international courts enjoy a great deal of procedural autonomy. For example, under Article 15 of its statute, the ICTY was granted the competence to adopt the rules of procedure and evidence for the conduct of the pre-trial phase of the proceedings, trials and appeals, the admission of evidence, the protection of victims and witnesses and other appropriate matters. In turn, in the case of the ECHR, there is no statute; the ECHR procedure was laid down in the European Convention of Human Rights and in the Rules of the Court, which were adopted by a plenary court under Article 25 of the ECHR, expressing the procedural autonomy of the ECHR.

International courts give their decisions in accordance with their jurisdiction. As already mentioned, the ICJ remains the only world court with general jurisdiction, having the competence to decide all disputes of a legal nature that are submitted to it by states. As for other international

73 A. Wyrozumska, Prawotwórcza działalność sq̨dów międzynarodowych i jej granice [Lawmaking by the International Courts and Its Limits], [in:] A. Wyrozumska, 'Granice swobody orzekania sądów międzynarodowych' [Limits of Discretion of International Courts], Faculty of Law and Administration, Uniwersytet Łódzki, Łódź 2014, at p. 51. 
courts, their jurisdiction is specialised and concerns matters of (i) criminal liability of an individual for committing international crimes, in the case of international criminal courts; (ii) deciding on violations of human rights, in the case of human rights courts, and (iii) deciding about economic matters, in the case of courts established by regional organisations dealing with economic cooperation and integration. The basic principle applicable to the jurisdiction of international courts is the competence-competence principle, according to which courts are empowered to determine their own jurisdiction to deal with the substantive claims in dispute. If a court has jurisdiction over legal disputes, it must have the power to decide whether there is a dispute and, if so, whether the dispute is a legal one. It is essential since, if there is a dispute over jurisdiction, that dispute needs to be decided before the court can address the merits. As Shelton observed, a court lacking the power to resolve this issue would either have to accept all applications filed, rejecting any challenges to its jurisdiction, or uphold all challenges and dismiss each case in which jurisdiction is questioned. ${ }^{74}$

A lack of jurisdiction results in inadmissibility, i.e. it is impossible for the court to consider and decide the case. Some courts (the ICJ and the ICLS) treat jurisdiction and admissibility as two separate issues and differentiate between the bases for determining jurisdiction and admissibility criteria. Therefore, it may happen that despite the court finding that it has jurisdiction to hear a given case, it may nevertheless be unable to decide it due to inadmissibility. Other courts (the CJUE and the ECHR) find that the examination of jurisdiction is one of the elements of the admissibility procedure. ${ }^{75}$

Another important factor connected with the internal legality is the position of international courts towards their own case law. Although the doctrine of precedent, in the sense known in the common law countries, is not applicable in international law, international courts tend to rely on their own judgments, due to a variety of reasons. First of all, the need for stable and coherent case law is paramount. The predictability of courts' decisions enhances their authority and legitimacy. ${ }^{76}$ It is also justified by

74 D. Shelton, op. cit., at p. 547.

75 A. Czaplińska, Określanie własnej kompetencji przez sq̨dy międzynarodowe - granica czy przejaw swobody orzeczniczej? [Self-determination of Competences by International Courts - Limit or Manifestation of Judicial Discretion], [in:] A. Wyrozumska, 'Granice swobody..., op. cit., at p. 89.

${ }^{76}$ Ch. Shreuer, M. Weiniger, A Doctrine of Precedent?, [in:] P. Muchlinski, F. Ortino, Ch. Schreuer, 'The Oxford Handbook of International Investment Law', Oxford Handboks, Oxford University Press, Oxford 2008, at p. 1190. 
the principle of legal certainty. Therefore, international courts, such as the ECHR, treat their previous judgments as de facto precedents, allowing them to develop the Convention law. ${ }^{77}$ In order for international courts to depart from their established line of case law, there must be a good reason. For example, the ECHR may depart from its earlier judgment if there are 'cogent reasons' for doing so. It may decide so especially when social changes and present-day conditions justify the new dynamic interpretation of the European Convention under the so-called "living instrument" doctrine. As Guillaume observed, "to constantly follow precedent also freezes the law, and prevents it from progressing according to new demands of society. A balance must be found for the judge and arbitrator between the necessary certainty and the necessary evolution of the law." ${ }^{.78}$

\section{Conclusion}

The proliferation of international courts and tribunals has not, by itself, rendered international law a real law, as postulated by Hart. However, it cannot be denied that the dynamic development of diversified international courts has changed the face of international law in the past few decades and will continue to do so in the future. The widespread compulsory jurisdiction in the meaning outlined above is crucial to strengthening the commitment of states to adhere to their international obligations. In this sense, one might argue that Hart was right in claiming that the functioning of courts endowed with compulsory jurisdiction is one of the conditions for recognising that international law is really law.

However, the impact of the judicialisation of international law over the past few decades should not be overestimated. The unevenness of the proliferation of international courts, in respect of geographic coverage as well as the subject matter of jurisdiction, and the often specialised kind of jurisdiction seem to considerably diminish the impact of judicialisation on the system of international law as a whole.

77 M. Balcerzak, Zagadnienie precedensu w prawie międzynarodowym praw człowieka [The Problem of Judicial Precedent in International Human Rights Law], Torun 2008, at pp. 143-232, 270-271.

${ }^{78}$ G. Guillaume, The Use of Precedent by International Judges and Arbitrators, 'Journal of International Dispute Settlement' 2011, vol. 2, no 1, at p. 6. 
Moreover, it is not certain whether the trend towards further judicialisation of international law will continue in the future. The specific geo-political situation in the world politics of the 1990s favoured the creation of courts and tribunals. However, the situation in the second decade of the $21^{\text {st }}$ century is largely different. According to some authors, there are grounds for optimism in this respect. For example, Kingsbury asserts that "current global politics remain, in aggregate, reformist rather than rejectionist with regards to judicialization." ${ }^{79}$ Although the prospects regarding the continuing trend towards judicialisation remain uncertain, depending on a number of political factors, the influence that international courts and tribunals have had on international law, thus far, should not be disregarded. According to Hart, international law can be a real law only if it becomes analogous in form to municipal law. He was aware that it may be a long process when he wrote that "[p]erhaps international law is at present in a stage of transition towards acceptance of this and other forms which would bring it nearer the structure to a municipal system." ${ }^{80}$ International courts and tribunals, despite being endowed with compulsory jurisdiction, cannot be equalled with courts operating in a municipal system. Nevertheless, it is also true that the proliferation of international courts and tribunals can be perceived as one of the important components of the dynamic transition of international law. Therefore, it could be justified to conclude by saying that, because of judicialisation, international law is closer to legalism now than it was at the beginning of the $20^{\text {th }}$ century. 


\section{Bibliography}

1. Alter K.J., The Multiplication of International Courts and Tribunals After the End of the Cold War, [in:] Romano C.P.R., Alter K.J., Shany Y. (eds.), 'The Oxford Handbook of International Adjudication', Oxford University Press, 2014.

2. Anand R.P., Compulsory Jurisdiction of the International Court of Justice, Hope India Pulications, Delhi 2008.

3. Balcerzak M., Zagadnienie precedensu w prawie międzynarodowym praw człowieka, Wydawnictwo TNOiK, Torun 2008.

4. Cassese A., The International Court of Justice: It is High Time to Restyle the Respected Old Lady, [in:] Cassese A., 'Realizing Utopia. The Future of International Law', Oxford University Press, Oxford 2012.

5. Chimni B.P., Legitimating the international rule of law, [in:] Crawford J., Koskenniemi M., Ranganathan P., 'The Cambridge Companion to International Law', Cambridge University Press, Cambridge 2012.

6. Czaplińska A., Określanie własnej kompetencji przez sądy międzynarodowe granica czy przejaw swobody orzeczniczej?, [in:] Wyrozumska A., 'Granice swobody orzekania sądów międzynarodowych', Faculty of Law and Administration, Uniwersytet Łódzki, Łódź 2014.

7. Czapliński W., Multiplikacja sq̨dów międzynarodowych - szansa czy zagrożenie dla jedności prawa międzynarodowego, [in:] Kolasa J., Kozłowski A., 'Rozwój prawa międzynarodowego - jedność czy fragmentacja’, Wrocław 2007.

8. Dupuy P.M., Vinuales J.E., The Challenge of "Proliferation": An Anatomy of the Debate, [in:] Romano C.P.R., Alter K.J., Shany Y. (eds.), 'The Oxford Handbook of International Adjudication', Oxford University Press, 2014.

9. Fachiri, A.P. The Permanent Court of International Justice, London 1932.

10. Guillaume G., The Use of Precedent by International Judges and Arbitrators, 'Journal of International Dispute Settlement' 2011, vol. 2, no 1.

11. Hart H.L.A., The Concept of Law, Oxford University Press, Oxford 1984 .

12. Kingsbury B., International Courts: Uneven Judicialisation in Global Order, [in:] Crawford J., Koskenniemi M. , Ranganathan P., 'The Cambridge Companion to International Law', Cambridge University Press, Cambridge 2012.

13. Kelsen, H. The Law of the United Nations, Stevens \& Sons Ltd., London 1950.

14. Kwiecień R., Teoria i filozofia prawa międzynarodowego. Problemy wybrane, Difin, Warszawa 2011.

15. Mik C., Ius cogens we współczesnym prawie międzynarodowym, [in:] Wnukiewicz-Kozłowska A., 'Aksjologia współczesnego prawa międzynarodowego', Wydawnictwo Uniwersytetu Wrocławskiego, Wrocław 2011.

16. O'Connel, M.E., Venderzee L., The History of International Adjudication, [in:] Romano C.P.R., Alter K.J., Shany Y., 'The Oxford Handbook of International Adjudication', Oxford University Press, Oxford 2014. 
17. Pauwelyn J., Salles L.E., Forum Shopping before International Tribunals: (Real) Concerns, (Im)Possible Solutions, 'Cornell International Law Journal' 2009, vol. 42, no 1.

18. Posner E.A., The Perils of Global Legalism, The University of Chicago Press, Chicago 2009.

19. Romano C.P.R., Alter K.J., Shany Y., Mapping International Adjudicative Bodies, The Issues, and Players, [in:] Romano C.P.R., Alter K.J., Shany Y., 'The Oxford Handbook of International Adjudication', Oxford University Press, 2014

20. Romano C.P.R., The Shift from the Consensual to the Compulsory Paradigm in International Adjudication: Elements for a Theory of Consent, 'International Law and Politics' 2007, vol. 39.

21. Romano C.P.R., Trial and Error in International Judicialization, [in:] Romano C.P.R., Alter K.J., Shany Y. (eds.), 'The Oxford Handbook of International Adjudication', Oxford University Press, 2014.

22. Shany Y., Competing Jurisdictions of International Courts and Tribunals, Oxford University Press, Oxford 2003.

23. Shany Y., Assessing the Effectiveness of International Courts, Oxford University Press, Oxford 2014.

24. Shelton D., Form, Function, and the Powers of International Courts, 'Chicago Journal of International Law' 2009, vol. 9, no 2.

25. Shklar J. N., Legalism: Law, Morals, and Political Trial, Harvard University Press, Cambridge, Mass. 1964.

26. Socha E., Karna odpowiedzialność jednostki $w$ prawie międzynarodowym, 'Kwartalnik Prawa Publicznego' 2002, vol. 2, no 4.

27. Shreuer Ch., Weiniger M., A Doctrine of Precedent? [in:] Muchlinski P., Ortino F., Schreuer Ch., 'The Oxford Handbook of International Investment Law', Oxford Handboks, Oxford University Press, Oxford 2008.

28. Tladi D.D., Jus cogens, Annex to the Report of the International Law Commission on the work of its sixty-sixth session (Agenda item 78), http:// legal.un.org/ilc/reports/2014/english/annex.pdf, point 3.

29. West R., Reconsidering Legalism, 'Minnesota Law Review' 2003, vol. 88.

30. Wyrozumska A., Prawotwórcza działalność sq̨dów międzynarodowych i jej granice, [in:] Wyrozumska A., 'Granice swobody orzekania sądów międzynarodowych', Faculty of Law and Administration, Uniwersytet Łódzki, Łódź 2014.

31. Zajadło J., Dylematy humanitarnej interwencji, Arche, Gdańsk 2005. 